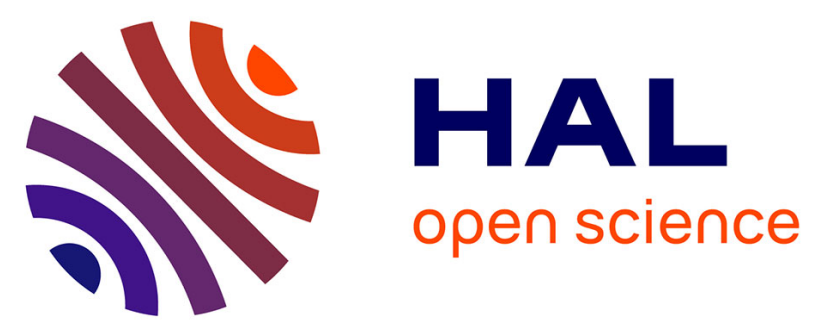

\title{
Contacts for Monolithic 3D architecture: Study of Ni_0.9Co_0.1 Silicide Formation
}

\author{
Philippe Rodriguez, S. Favier, F Nemouchi, C Sésé, F Deprat, C. \\ Fenouillet-Beranger, P. Gergaud
}

\section{- To cite this version:}

Philippe Rodriguez, S. Favier, F Nemouchi, C Sésé, F Deprat, et al.. Contacts for Monolithic 3D architecture: Study of Ni_0.9Co_0.1 Silicide Formation. 2016 IEEE International Interconnect Technology Conference / Advanced Metallization Conference (IITC/AMC), May 2016, San Jose, United States. 10.1109/IITC-AMC.2016.7507685 . cea-01615601

\section{HAL Id: cea-01615601 https://hal-cea.archives-ouvertes.fr/cea-01615601}

Submitted on 12 Oct 2017

HAL is a multi-disciplinary open access archive for the deposit and dissemination of scientific research documents, whether they are published or not. The documents may come from teaching and research institutions in France or abroad, or from public or private research centers.
L'archive ouverte pluridisciplinaire HAL, est destinée au dépôt et à la diffusion de documents scientifiques de niveau recherche, publiés ou non, émanant des établissements d'enseignement et de recherche français ou étrangers, des laboratoires publics ou privés. 


\title{
Contacts for Monolithic 3D architecture: Study of $\mathrm{Ni}_{0.9} \mathrm{Co}_{0.1}$ Silicide Formation
}

\author{
Ph. Rodriguez*, S. Favier*†, F. Nemouchi*, C. Sésé*, F. Deprat*, C. Fenouillet-Beranger*, P. Gergaud* \\ ${ }^{*}$ Univ. Grenoble Alpes, F-38000 Grenoble, France \\ CEA, LETI, MINATEC Campus, F-38054 Grenoble, France. \\ Email: philippe.rodriguez@cea.fr \\ ${ }^{\dagger}$ STMicroelectronics, 850 rue Jean Monnet, BP 16, 38926 Crolles, France
}

\begin{abstract}
In this work, we studied the solid-state reaction between a $\mathrm{Ni}_{0.9} \mathrm{Co}_{0.1}$ film and a silicon substrate. NiCo silicide is considered to substitute Ni- and NiPt-based silicides in 3D integration in order to extend the bottom transistor thermal stability. Thanks to the combined analysis of sheet resistance data, $X$-ray reflectivity spectra modelling, $X$-ray diffraction and wavelength dispersive $\mathrm{X}$-ray fluorescence analyses on $\mathrm{Ni}_{0.9} \mathrm{Co}_{0.1} / \mathrm{Si}$ samples annealed at various temperatures, we were able to describe the phase sequence of the NiCo silicide formation.
\end{abstract}

Keywords-NiCo, silicide, solid-state reaction

\section{INTRODUCTION - CONTEXT}

In the past half-century, the integrated circuit (IC) industry has been growing rapidly, benefiting from the dimensional downscaling of transistors according to Moore's law as well as larger wafer sizes. This downscaling results in higher performance, lower power consumption, more complex functionality, faster device speeds, and lower cost per transistor. 3D integration is regularly mentioned for its potential in decreasing costs, variability and delay in interconnections limiting nowadays ICs performance. The CoolCube ${ }^{\mathrm{TM}} 3 \mathrm{D}$ or sequential $3 \mathrm{D}$ integration is a serious alternative approach to conventional planar integration for future nodes [1], [2].

However this integration faces the challenge to realize a high performance transistor at the top level without degrading the electrical characteristics of the bottom one. Previous work highlighted that silicide is the main responsible of bottom transistor thermal stability degradation beyond $500{ }^{\circ} \mathrm{C}$ [3]. Even if addition of Pt in Ni-based silicides allows extending the monosilicide thermal stability (by increasing the barrier of nucleation of $\mathrm{NiSi}_{2}$ ) [4], thermal budget involved for the elaboration of top level irremediably leads to morphological degradation and the subsequent deterioration of contact properties (i.e. increase of leakage or even shorts in the junctions) [3].

We investigated the addition of $10 \%$ of $\mathrm{Co}$ in $\mathrm{NiSi}$ silicide in order to extend its thermal stability and to propose an alternative to Ni- and NiPt-based silicides. Indeed, if Pt is soluble in the monosilicide NiSi phase, Co is not. This element is thus expected to be mainly located at the surface and on grain boundaries within the silicide film and to affect the disilicide formation trough other mechanisms than $\mathrm{Pt}$ (i.e. surface/interface energy effects) [5], [6]. In this work, we studied the solid-state reaction between a $\mathrm{Ni}_{0.9} \mathrm{Co}_{0.1}$ film and a silicon substrate after several annealing processes at temperatures ranging from 180 to $800{ }^{\circ} \mathrm{C}$.

\section{EXPERIMENTAL DETAILS}

$\operatorname{TiN}(7 \mathrm{~nm}) / \mathrm{Ni}_{0.9} \mathrm{Co}_{0.1}(7 \mathrm{~nm}) / 300 \mathrm{~mm} \mathrm{Si}(100)$ substrate samples were prepared using RF-PVD chambers. Before metal deposition, $\mathrm{Si}$ substrates were treated by HF $0.5 \%$ solution and by in situ dry $\mathrm{NF}_{3} / \mathrm{NH}_{3}$ based chemical etch and anneal. In situ pretreatment and metal deposition were carried out in a $300 \mathrm{~mm}$ Applied Materials Endura platform dedicated to silicide process. After metal deposition, samples were annealed in a Levitech Levitor 4300 tool dedicated to advanced Rapid Thermal Annealing (RTA) processes at temperatures ranging from 180 to $800{ }^{\circ} \mathrm{C}$ for $30 \mathrm{~s}$ and under $\mathrm{N}_{2}$ atmosphere. Finally, samples were treated in hot $\mathrm{H}_{2} \mathrm{O}_{2} / \mathrm{H}_{2} \mathrm{SO}_{4}$ solution followed by $\mathrm{NH}_{4} \mathrm{OH} / \mathrm{H}_{2} \mathrm{O}_{2}$ solution in a Screen SU-3100 single wafer cleaner in order to selectively remove metallic phases without impacting silicides.

The sheet resistance of samples was measured by using a fully automatic 4 point probe sheet resistance Napson WS3000 tool, X-ray reflectivity (XRR) spectra were acquired on a Jordan Valley JVX5200 X-ray reflectometer, in plane X-ray diffraction (XRD) was performed on Rigaku SmartLab highresolution X-ray diffractometer and Wavelength Dispersive Xray Fluorescence (WDXRF) was realised on Rigaku AZX400 sequential WDXRF spectrometer.

\section{RESULTS \& DISCUSSION}

Figure 1 plots the $\mathrm{R}_{\text {sheet }}$ of the samples right after annealing (circles) and after selective etching (crosses) at temperatures ranging from $180{ }^{\circ} \mathrm{C}$ to $800{ }^{\circ} \mathrm{C}$.

Right after annealing, four areas can be observed. Between $180{ }^{\circ} \mathrm{C}$ and $260{ }^{\circ} \mathrm{C}$, the sheet resistance is increasing from $58 \Omega / \square$ to $85 \Omega / \square$. Then, between $280{ }^{\circ} \mathrm{C}$ and $320{ }^{\circ} \mathrm{C}$ a plateau around $87 \Omega / \square$ is noticed. From $320{ }^{\circ} \mathrm{C}$ to $400{ }^{\circ} \mathrm{C}$ sheet resistance is decreasing until reaching a minimum value at around $18 \Omega / \square$ which is nearly constant (a slight decrease is noticed) between $400{ }^{\circ} \mathrm{C}$ and $800{ }^{\circ} \mathrm{C}$. The selective etching consists in the removal of TiN and unreacted NiCo layers, this leads to a modification of the sheet resistance behaviour and values, especially in the two first areas. Indeed, after selective etching, the sheet resistance is only governed by the silicide's formation and its increase of thickness. Thus, sheet resistance variations can be explained by thickness measurements performed by XRR.

Figure 2 shows the modelling of XRR spectra after annealing (Fig. 2a) and after selective etching (Fig. 2b). 


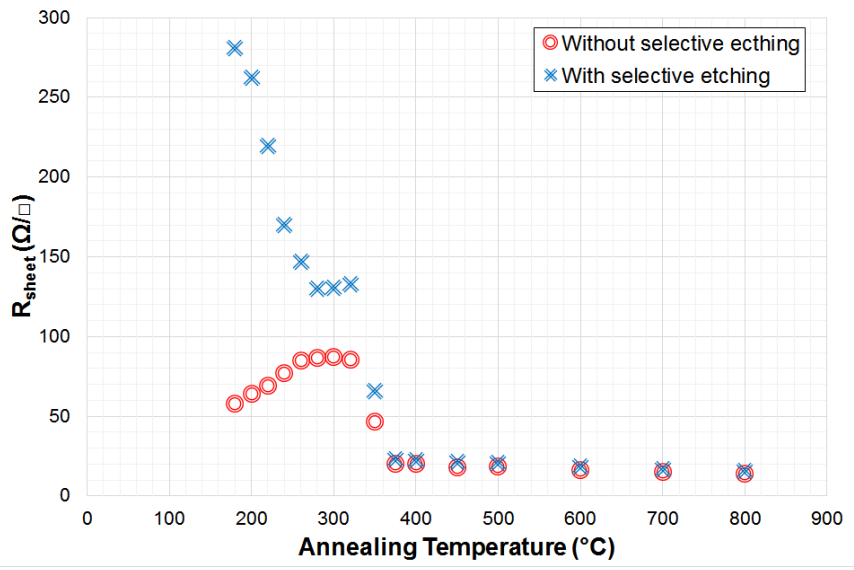

Fig. 1. Sheet resistance measured after annealing $\mathrm{Ni}_{0.9} \mathrm{Co}_{0.1}(7 \mathrm{~nm})$ on $\mathrm{Si}$ substrate at various temperatures for $30 \mathrm{~s}$ under $\mathrm{N}_{2}$. The sheet resistances of annealed samples with and without selective etching are indicated by crosses and circles, respectively.

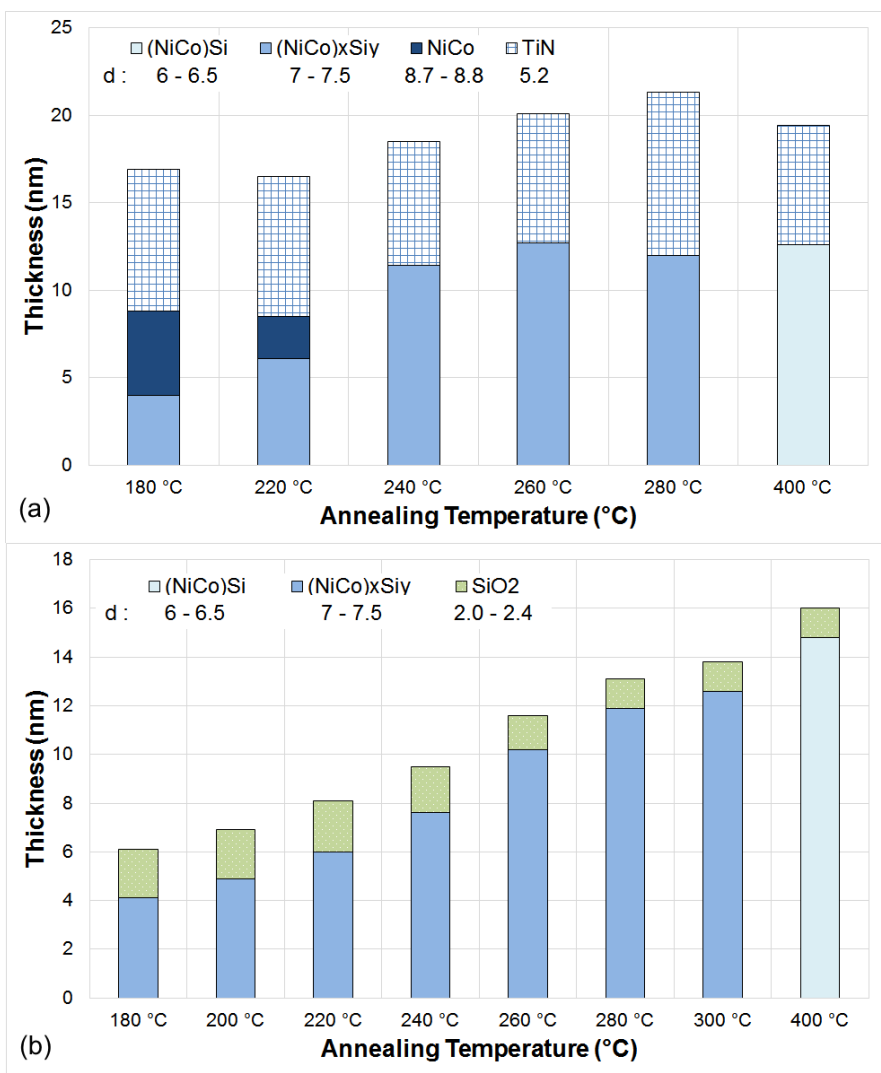

Fig. 2. XRR spectra modelling without selective etching (a) and with selective etching (b) of TiN $(7 \mathrm{~nm}) / \mathrm{Ni}_{0.9} \mathrm{Co}_{0.1}(7 \mathrm{~nm}) / \mathrm{Si}$ samples at various annealing temperatures.

The analysis of XRR spectra modelling exhibits a complex variation of phase sequence depending on the annealing temperature. At low temperature and without selective etching, the thickness of the denser phase $(8.7-8.8)$ has been attributed to the unreacted NiCo (bulk theoretical density: 8.9). The NiCo thickness decrease with increasing temperature and no more $\mathrm{NiCo}$ is detected beyond $220{ }^{\circ} \mathrm{C}$. In this range of temperature, the metal NiCo is consumed for the benefit of the formation of a metal rich intermetallic compound $\left(\mathrm{NiCo}_{\mathrm{x}} \mathrm{Si}_{\mathrm{y}}\right.$ [7], [8] with a density of about $7-7.5$. For simplification purpose, XRR modelling of metal rich silicide has been depicted as one phase on figure 2 but two layers with two distinct densities are necessary in order to obtain a good fitting of experimental XRR spectra. After selective etching, metallic layers (TiN and unreacted $\mathrm{NiCo}$ ) are removed and a $\mathrm{SiO}_{2}$ passivation layer is observed [9]. Spectra modelling exhibits that the thickness of $(\mathrm{NiCo})_{\mathrm{x}} \mathrm{Si}_{\mathrm{y}}$ layer increases with annealing temperature until reaching a plateau at around $280-300{ }^{\circ} \mathrm{C}$. At higher temperature, typically $400{ }^{\circ} \mathrm{C}$, modelling shows that a phase with a density around $6-6.5$ is obtained. This phase has been attributed to the monosilicide (NiCo)Si thanks to XRD analyses.

Figure 3 shows the in-plane XRD spectra of samples after annealing at various temperatures and without selective etching.

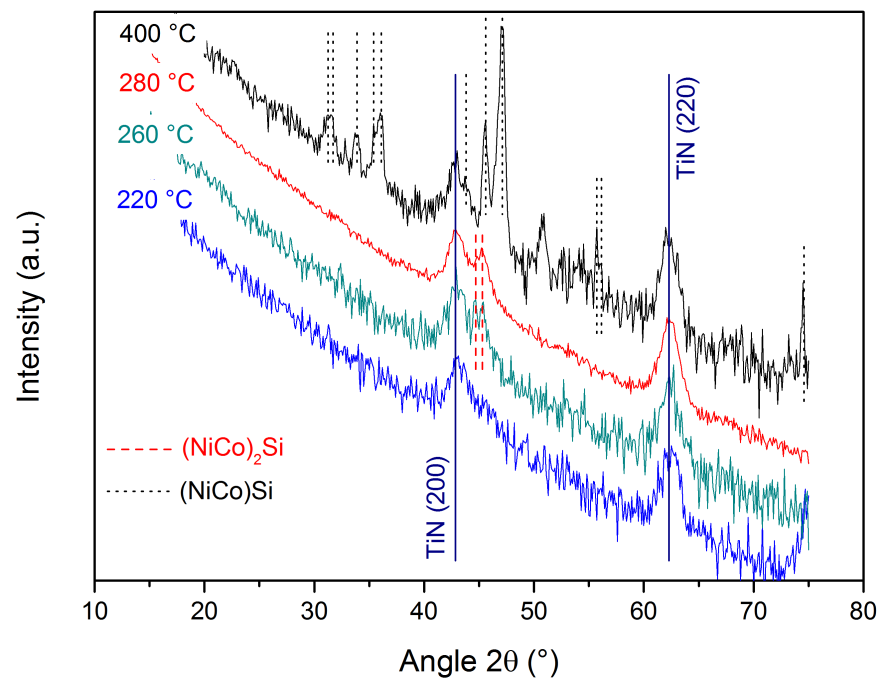

Fig. 3. In-plane XRD spectra of $\mathrm{TiN}(7 \mathrm{~nm}) / \mathrm{Ni}_{0.9} \mathrm{Co}_{0.1}(7 \mathrm{~nm}) / \mathrm{Si}$ samples annealed at various temperatures and without selective etching.

Thanks to JCPDS database and CaRIne Crystallography modelling, we were able to index most of the diffraction peaks of XRD spectra. TiN (200) and (220) peaks have been identified on all the XRD spectra. At 260 and $280{ }^{\circ} \mathrm{C}$, two peaks have been attributed to a $\mathrm{Ni}_{2} \mathrm{Si}$-like phase labelled $(\mathrm{NiCo})_{2} \mathrm{Si}$ and corresponding to a metal rich phase. At $400{ }^{\circ} \mathrm{C}$, numerous diffraction peaks appear, they have been indexed using an orthorhombic NiSi-like phase and related to the formation of the monosilicide (NiCo)Si phase. The indexation of peak located at $50.8^{\circ}$ remains unclear.

The addition of $10 \%$ of Co allows extending the thermal stability of $(\mathrm{NiCo}) \mathrm{Si}$ by repelling the formation of the more resistive disilicide phase ( $\mathrm{NiCo}) \mathrm{Si}_{2}$. In order to specify the role of $\mathrm{Co}$ and its incorporation into silicides, WDXRF analyses have been performed. The evolution of Co rate after selective etching is depicted on figure 4 .

Important fluctuations of Co rate are observed depending on annealing temperature. Indeed, from $180{ }^{\circ} \mathrm{C}$ to $220{ }^{\circ} \mathrm{C}$, Co rate decrease with increasing temperature, then it tends to stabilize at around $6.5 \%$ at. at $220-260{ }^{\circ} \mathrm{C}$. Finally, for higher annealing temperatures, the Co rate increases until it reaches 


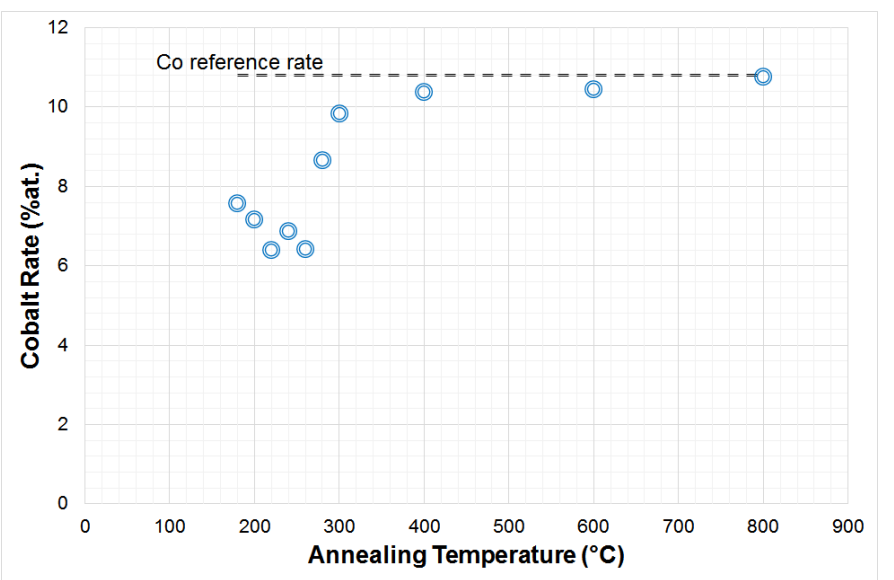

Fig. 4. Evolution of Co rate (\%at.) measured by WDXRF of $\mathrm{Ni}_{0.9} \mathrm{Co}_{0.1}$ (7 $\mathrm{nm}) / \mathrm{Si}$ samples annealed at various temperatures and after selective etching.

its nominal rate (10.5\%at., previously determined on $\mathrm{NiCo}$ as-deposited film) at $400{ }^{\circ} \mathrm{C}$. From the previous analyses, we observe that a small amount of $\mathrm{Co}$ is incorporated into the metal rich phase (i.e. $\left.(\mathrm{NiCo})_{\mathrm{x}} \mathrm{Si}_{\mathrm{y}}\right)$. As a matter of fact, the incorporating Co rate is far less than $10 \%$ at. Beyond $300{ }^{\circ} \mathrm{C}$ the monosilicide (NiCo)Si starts to form and the stabilized phase (since $400{ }^{\circ} \mathrm{C}$ ) seems to tolerate the incorporation of $\mathrm{Co}$ at its nominal rate. The behaviour of $\mathrm{Co}$ rate at low temperatures is surprising, thickness of silicide is very low but the $\mathrm{Co}$ rate is higher than for annealing temperatures at around $250{ }^{\circ} \mathrm{C}$.

Thanks to the combined analysis of sheet resistance data, XRR spectra modelling, XRD spectra analyses and WDXRF results, we can explain in details the phase sequence of $\mathrm{Ni}_{0.9} \mathrm{Co}_{0.1}$ silicide formation. At low temperature, at least two main phases coexist: $\mathrm{NiCo}$ and $(\mathrm{NiCo})_{\mathrm{x}} \mathrm{Si}_{\mathrm{y}}$. NiCo phase is gradually consumed and leads to the concurrent formation of $(\mathrm{NiCo})_{\mathrm{X}} \mathrm{Si}_{\mathrm{y}}$. In fact, regarding the XRR and WDXRF results, we assume the formation of two metal-rich silicide phases in which Co has not the same solubility. One of the two phases, probably the one in which the Co rate is the highest, is partially removed during the selective etching due to a poor $\mathrm{Si} \%$ at. content. At $280-320{ }^{\circ} \mathrm{C}$, the transformation is completed and the temperature is still to low to initiate the formation of the monosilicide (NiCo)Si. Beyond $320^{\circ} \mathrm{C}$, the formation of $(\mathrm{NiCo}) \mathrm{Si}$ is initiated until reaching $400{ }^{\circ} \mathrm{C}$. At this point, the monosilicide ( $\mathrm{NiCo}) \mathrm{Si}$ is formed and it is stable until temperatures such as $800{ }^{\circ} \mathrm{C}$.

\section{CONCLUSION}

For 3D integration and in order to extend the thermal stability of the bottom transistor, we introduced the use of $\mathrm{Ni}_{0.9} \mathrm{Co}_{0.1}$ silicide. We studied the solid-state reaction between a $7 \mathrm{~nm}$ thick $\mathrm{Ni}_{0.9} \mathrm{Co}_{0.1}$ film and a silicon substrate after various annealing processes at temperatures ranging from 180 to $800{ }^{\circ} \mathrm{C}$. Thanks to the combined analysis of sheet resistance data, X-ray reflectivity spectra modelling and X-ray diffraction analyses, we described the phase sequence of the NiCo silicide formation. The additional wavelength dispersive $\mathrm{X}$-ray fluorescence analyses tend to exhibit the formation of two metal-rich phases at low temperatures. Beyond $320{ }^{\circ} \mathrm{C}$, the formation of the monosilicide $(\mathrm{NiCo}) \mathrm{Si}$ is initiated and this latter is completed at $400{ }^{\circ} \mathrm{C}$. The $(\mathrm{NiCo}) \mathrm{Si}$ phase appears to be stable until temperatures such as $800{ }^{\circ} \mathrm{C}$.

From a material point of view, NiCo silicide seems to be promising in order to extend the thermal stability of the bottom transistor's silicide in 3D integration. This material have been implemented on 14-FDSOI technology and its electrical performances have been studied [10].

\section{ACKNOWLEDGMENTS}

This research was supported by the French National Research Agency (ANR) under the "Investissements d'avenir" program: ANR-11-EQPX-0010 and FDSOI11 and by Nano2017 project.

Authors would like to thank V. Loup et D. Marseilhan for their assistance with selective etching and thermal annealing.

\section{REFERENCES}

[1] P. Batude, M. Vinet, B. Previtali, C. Tabone, C. Xu, J. Mazurier, O. Weber, F. Andrieu, L. Tosti, L. Brevard, B. Sklenard, P. Coudrain, S. Bobba, H. Ben Jamaa, P. Gaillardon, A. Pouydebasque, O. Thomas, C. Le Royer, J. Hartmann, L. Sanchez, L. Baud, V. Carron, L. Clavelier, G. De Micheli, S. Deleonibus, O. Faynot, and T. Poiroux, "Advances, challenges and opportunities in 3D CMOS sequential integration," in 2011 IEEE International Electron Devices Meeting (IEDM), Dec 2011, pp. 7.3.1-7.3.4.

[2] M. Vinet, P. Batude, C. Tabone, B. Previtali, C. LeRoyer, A. Pouydebasque, L. Clavelier, A. Valentian, O. Thomas, S. Michaud, L. Sanchez, L. Baud, A. Roman, V. Carron, F. Nemouchi, V. Mazzocchi, H. Grampeix, A. Amara, S. Deleonibus, and O. Faynot, "3D monolithic integration: Technological challenges and electrical results," Microelectron. Eng., vol. 88, no. 4, pp. $331-335,2011$.

[3] C. Fenouillet-Beranger, B. Previtali, P. Batude, F. Nemouchi, M. Cassé, X. Garros, L. Tosti, N. Rambal, D. Lafond, H. Dansas, L. Pasini, L. Brunet, F. Deprat, M. Grégoire, M. Mellier, and M. Vinet, "FDSOI bottom MOSFETs stability versus top transistor thermal budget featuring 3D monolithic integration," Solid-State Electronics, vol. 113, pp. $2-8,2015$.

[4] D. Mangelinck, J. Y. Dai, J. S. Pan, and S. K. Lahiri, "Enhancement of thermal stability of NiSi films on (100)Si and (111)Si by Pt addition," Appl. Phys. Lett., vol. 75, no. 12, pp. 1736-1738, 1999.

[5] C. Lavoie, C. Detavernier, C. C. Jr., F. d'Heurle, A. Kellock, J. JordanSweet, and J. Harper, "Effects of additive elements on the phase formation and morphological stability of nickel monosilicide films," Microelectron. Eng., vol. 83, no. 11-12, pp. 2042 - 2054, 2006.

[6] C. Detavernier, D. Deduytsche, J. Jordan-Sweet, C. Cabral, and C. Lavoie, "Influence of alloying elements on the formation and stability of NiSi," ECS Trans., vol. 3, no. 2, pp. 131-138, 2006.

[7] C. Detavernier, R. L. Van Meirhaeghe, F. Cardon, and K. Maex, "Influence of mixing entropy on the nucleation of $\mathrm{CoSi}_{2}$," Phys. Rev. $B$, vol. 62, pp. 12045-12051, 2000.

[8] E. Bourjot, M. Putero, C. Perrin-Pellegrino, P. Gergaud, M. Gregoire, F. Nemouchi, and D. Mangelinck, "Kinetics study of $\mathrm{NiPt}\left(10\right.$ at.\%)/ $\mathrm{Si}_{0.7} \mathrm{Ge}_{0.3}$ solid state reactions," Microelectron. Eng., vol. 120, pp. 163 - 167, 2014.

[9] V. Carron, M. Ribeiro, P. Besson, G. Rolland, J.-M. Hartmann, V. Loup, S. Minoret, L. Clavelier, C. Leroyer, and T. Billon, "Nickel selective etching studies for self-aligned silicide process in $\mathrm{Ge}$ and SiGe-based devices," ECS Trans., vol. 3, no. 7, pp. 643-654, 2006.

[10] F. Deprat, F. Nemouchi, C. Fenouillet-Beranger, M. Cassé, P. Rodriguez, M. Danielou, S. Favier, P. Batude, and M. Vinet, "First integration of NiCo $10 \%$ at. on pMOS transistors," in Abstract submitted to IITC/AMC, 2016. 